\title{
Pengaruh Servant Leadership Terhadap Psychological Capital Prajurit TNI AD di Pusat Pendidikan Infanteri
}

\author{
Ardiya Dwiyanto Wibowo ${ }^{1}$, Endah Andriani Pratiwi ${ }^{2}$ \\ ${ }^{1}$ Fakultas Psikologi Universitas Jenderal Achmad Yani Cimahi \\ 1ªrdiyawibowo@gmail.com
}

\begin{abstract}
This research is a causal study between Servant Leadership and Psychological Capital Army soldier at the Infantry Education Center. The purpose of this study was to determine whether or not there was an influence between Servant Leadership and Army Soldier Psychological Capital in the Infantry Education Center. Servant Leadership is the first person to provide services. It begins with a natural feeling that people want to be served, serve first. Then the conscious choice leads one to take the lead (Greenleaf, 1999). Meanwhile, Psychological Capital is a part of positive psychology that is owned by each individual which is useful to help that individual to develop with Self-efficacy, Hope, Optimism and Resilience (Luthans, Youssef \& Avolio, 2007). The samples of this study are 147 Army soldiers in the Infantry Education Center with the rank of Perwira, Bintara and Tamtama who are obtained by probability sampling techniques. The results showed the influence of Servant Leadership on Psychological Capital Army Soldiers in Infantry Education Center with the $R^{2}$ value obtained is 0.469, meaning that the effect of Servant Leadership on soldier Psychological Capital is 46\%. The most influencing aspect of Servant Leadership is the Wisdom aspect, in addition to that Psychological Capital Soldiers are dominated by bintara in the Self Efficacy, Hope, and Optimism aspects. Meanwhile, perwira in Resilience aspect.
\end{abstract}

Key words: Servant Leadership, Psychological Capital, Army, Soldier

\begin{abstract}
Abstrak
Penelitian ini adalah studi kausal antara Servant Leadership dengan Psychological Capital Prajurit TNI AD di pusat Pendidikan Infanteri. Tujuan dari penelitian ini untuk mengetahui gambaran mengenai ada atau tidaknya pengaruh antara Servant Leadership dengan Psychological Capital Prajurit TNI AD di pusat Pendidikan Infanteri. "Servant Leadership adalah orang yang pertama memberikan pelayanan. Ini dimulai dengan perasaan alami bahwa orang ingin dilayani, melayani terlebih dahulu. Kemudian pilihan sadar membawa seseorang berkeinginan untuk memimpin (Greenleaf, 1999). Sedangkan Psychological Capital adalah suatu bagian dari psikologis positif yang dimiliki oleh setiap individu yang berguna untuk membantu individu tersebut untuk dapat berkembang dengan adanya Self-efficacy, Hope, Optimism and Resilience (Luthans, Youssef \& Avolio, 2007). Adapun
\end{abstract}


sampel penelitian ini adalah 147 orang Prajurit di pusat Pendidikan Infanteri dengan pangkat Perwira, Bintara dan Tamtama yang di dapatkan dengan teknik probability sampling. Hasil penelitian menunjukan adanya pengaruh Pengaruh Servant Leadership terhadap Psychological Capital Prajurit di pusat Pendidikan Infanteri dengan Nilai $\mathrm{R}^{2}$ yang diperoleh adalah sebesar 0.469 , artinya besarnya Pengaruh Servant Leadership terhadap Psychological Capital Prajurit sebesar 46\%. Aspek Servant Leadership yang paling mempengaruhi adalah aspek Wisdom, selain itu Psychological Capital Prajurit di dominasi oleh pangkat bintara pada aspek Self Efficacy, Hope, dan Optimism. Sedangkan Perwira pada aspek Resilience.

Kata kunci: Servant Leadership, Psychological Capital, TNI -AD, Prajurit

\section{Pendahuluan}

TNI merupakan alat negara di bidang pertahanan yang dalam menjalankan tugasnya berdasarkan kebijakan dan keputusan politik negara. Tugas pokok TNI adalah menegakkan kedaulatan negara, mempertahankan keutuhan wilayah Negara Kesatuan Republik Indonesia yang berdasarkan Pancasila dan Undang-Undang Dasar Negara Republik Indonesia Tahun 1945, serta melindungi segenap bangsa dan seluruh tumpah darah Indonesia dari ancaman dan gangguan terhadap keutuhan bangsa dan negara. Pusdikif adalah lembaga Pendidikan militer yang bernaung di bawah Pussenif kodiklat TNI AD memiliki peran yang sangat penting dalam membentuk dan menyiapkan prajurit sekaligus kader pemimpin masa depan sesuai tujuan dan sasaran pendidikan yang telah ditetapkan.

Dalam kehidupan militer saat ini, pentingnya pengembangan Psychological Capital terhadap prajurit Pusdikif, karena Pusdikif sendiri sebagai instansi yang telah berdiri selama kurang lebih 70 tahun, dan memiliki sekitar 800 orang prajurit yang bekerja setiap hari, serta menjadi lembaga Pendidikan milliter tentu memiliki tanggung jawab yang besar. Penting bagi seorang prajurit untuk memiliki Psychological Capital dengan adanya 4 indikator yaitu Self Efficacy Hope, Optimisme dan resiliensi. Dalam penelitian Psikologi Militer Sait Gurbuza and Hilal Bozkurt Yildirim (2018) tentang Psychological Capital dalam studinya menunjukkan bahwa mereka yang memiliki Psychological Capital lebih tinggi lebih cenderung menggambarkan kinerja tugas lebih baik, serta berkomitmen pada organisasi mereka, dan sangat puas dengan pekerjaan mereka di lingkungan militer. 
Penelitian lain dari Eduardo Hernández-Varas (2019) memperoleh Korelasi positif dan signifikan terdeteksi antara variabel Psychological Capital, Work Satisfaction dan Health Self-Perception mampu memprediksi Psychological Wellbeing, semuanya menjelaskan hingga 53\%. Prediktor yang paling penting adalah Psychological Capital yang bertanggung jawab atas $80 \%$ dari keseluruhan. Dengan kesimpulan kekuatan prediksi yang signifikan dari Psychological Capital atas work satisfaction dan health self-perception pengembangan program yang bertujuan untuk meningkatkan Psychological Capital mungkin memiliki hasil positif terhadap Psychological Wellbeing prajurit militer.

Dalam perkembangan zaman TNI AD memiliki slogan "Bersama Rakyat TNI Kuat" hal tersebut menjadikan upaya TNI AD untuk lebih dekat dengan masyarakat. Oleh karena itu di butuhkan para pemimpin yang dapat mengayomi dan melayani masyarakat, namun sebelum turun langsung kemasyarakat seorang pemimpin akan menerapkan kepada prajuritnya terlebih dahulu, dalam aktivitas pengolahan sumber daya manusia dibutuhkan gaya kepemimpinan yang dapat melayani dan tidak mementingkan dirinya sendiri. Dengan situasi sekarang pandemic Covid-19 seorang pemimpin harus mampu memahami situasi disekitarnya serta memperhatikan keadaan prajurit di tengah pandemic Covid-19. Gaya kepemimpinan merupakan perilaku atau cara yang di pilih dan digunakan pemimpin untuk bisa mempengaruhi pikiran, perasaan, sikap dan perilaku bawahanya.

Gary Yukl (1994) mengungkapkan bahwa pemimpin yang efektif mempengaruhi para pengikutnya untuk mempunyai optimisme yang lebih besar, rasa percaya diri, serta komitmen kepada tujuan dan misi organisasi. Dengan demikian cara-cara perilaku pemimpin dalam mengarahkan pengikutnya akan berpengaruh. Menurut Burns (1978) “Kepemimpinan Transformasional menyerukan nilai-nilai moral dari pengikut dalam upayanya untuk meningkatkan kesadaran mereka tentang masalah etis dan untuk memobilisasi energi dan sumber daya mereka untuk mereformasi institusi." Sedangkan gaya kepemimpinan Transaksional "Kepemimpinan yang melakukan transaksi memotivasi para pengikut dengan menyerukan kepentingan pribadi mereka.” (Yukl 2010:290). 
Selain Transformasional dan Transaksional gaya kepemimpinan yang dapat di gunakan adalah Servant Leadership. Servant leadership merupakan suatu gaya kepemimpinan yang berawal dari perasaan tulus yang timbul dari hati yang berkehendak untuk melayani. Pemimpin (servant leaders) menempatkan kebutuhan pengikut sebagai prioritas utama dan memperlakukannya sebagai rekan kerja, sehingga kedekatan antara keduanya sangatlah erat karena saling terlibat satu sama lain Greenleaf (1970). Menurut Barbuto dan Wheeler (2006) dan wong dan page (2003) Seorang pemimpin yang menerapkan gaya servant leadership akan selalu memberikan pelayanan yang baik kepada karyawanya sehingga karyawan memilik rasa percaya diri yang tinggi serta dapat membawa individu kearah yang lebih baik.

Pentingnya Servant Leadership bagi pemimpin TNI AD sejalan dengan 11 azaz kepemimpinan TNI-AD yaitu 1. Taqwa, yaitu beriman kepada Tuhan yang Maha Esa dan taat kepadanya. 2. Ing ngarsa sung tulada, yaitu memberi suri teladan dihadapan anak buah. 3. Ing madya mangun karsa, yaitu ikut bergiat serta menggugah semangat di tengah-tengah anak buah 4. Tut wuri handayani, yaitu mempengaruhi dan memberi dorongan dari belakang kepada anak buah. 5 . Waspada purba wisesa, yaitu selalu waspada, mengawasi serta sanggup dan berani memberi koreksi kepada anak buah. 6. Ambeg parama arta, yaitu dapat memilih dengan tepat mana yang harus dilakukan. 7. Prasaja, yaitu tingkah laku yang sederhana dan tidak berlebih-lebihan. 8. Satya, yaitu sikap loyal yang timbal balik, dari atasan terhadap bawahan, dari bawahan terhadap atasan dan kesamping 9. Gemi nastiti, yaitu kesabaran dan kemampuan untuk membatasi penggunaan dan pengeluaran segala sesuatu kepada yang benar-benar diperlukan. 10. Belaka, yaitu kemauan, kerelaan dan keberanian untuk mempertanggungjawabkan Tindakantindakannya. 11. Legawa, yaitu kemauan, kerelaan dan keikhlasan untuk pada saatnya menyerahkan tanggungjawab dan kedudukannya kepada generasi berikutnya. Dari 11 azaz kepemimpinan TNI-AD dengan dimensi Servant Leadership memiliki beberapa kesamaan dimana seorang pemimpin harus mengutamakan bawahanya dan mengayominya.

A. Gregory Stone (2003) menyatakan bahwa Fokus Pemimpin Transformasional diarahkan pada organisasi, dan berperilaku membangun 
komitmen pengikut terhadap tujuan organisasi, sedangkan pemimpin yang Servant Leadership fokus pada karyawan dan pencapaian tujuan organisasi adalah bawahannya. Sejauh mana pemimpin mampu mengalihkan fokus utama kepemimpinan dari organisasi kepada karyawan adalah faktor pembeda dalam mengklasifikasikan pemimpin Transformasional dan Servant Leadership.

Berdasarkan hasil penelitian yang di lakukan Eric D. Coggins (2012), yang pertama untuk mengukur model skala penuh Servant Leadership dengan empat sumber daya individu Psychological Capital Secara umum, temuan dari penelitian ini tampaknya mengkonfirmasi bahwa hubungan positif yang signifikan secara statistik mungkin ada antara Servant Leadership dan Psychological Capital. Sebagian besar, temuan menunjukkan bahwa Servant Leadership berhubungan positif dengan Psychological Capital dalam sampel Kamboja dan Amerika, tetapi hubungan itu ditemukan signifikan secara statistik dalam sampel Kamboja saja. Meskipun model yang dihasilkan secara umum positif, temuan menunjukkan bahwa lima komponen Servant Leadership dalam kombinasi dengan satu sama lain menambah atau mengurangi dari masing-masing model regresi linier yang terkait dengan komponen Psychological Capital individu dalam urutan dan besaran yang berbeda-beda.

Penelitian selanjutnya Eric D. Coggins (2015) menyatakan bahwa Servant Leadership memiliki pengaruh positif terkait dengan Psychological Capital dimana para pemimpin menunjukkan kepedulian terhadap kebutuhan dan pengembangan pengikut dan memberikan nilai tambah dalam hal kesejahteraan pengikut. Psychological capital telah dinyatakan sebagai salah satu ukuran sumber daya psikologis internal individu (pemimpin dan pengikut) yang relevan dengan kesejahteraan psikologis individu.

Menjadi seorang pemimpin di instansi militer tentu harus memiliki kompetensi yang baik dan memliki jiwa pemimpin. Mengapa pemimpin yang melayani di perlukan di instansi militer karena "keberhasilan tugas milik anak buah, namun kegagalan tanggung jawab seorang pemimpin”. TNI sebagai sebuah institusi pertahanan negara dituntut untuk melaksanakan arah kebijakan dalam bidang pertahanan dan keamanan negara, serta turut mempersiapkan sumber daya manusia 
yang memiliki komitmen, karakter positif, kreatif, kompetitif, komunikatif, kredibel dan militan bila dihadapkan dengan tuntutan tugas." Mantan Panglima TNI AD Gatot Nurmantyo (2017) www.tribunnews.com. Servant Leadership sendiri dalam sebuah organisasi merupakan hal penting, dalam instansi militer seorang pemimpin militer memiliki peranan besar dalam menentukan keberhasilan dalam pencapaian tujuan organisasi serta keberhasilan prajurit, dan organisasi membutuhkan prajurit yang penuh semangat serta miliki energi positif dalam bekerja, serta kemampuan menyerap diri dalam pekerjaan di masa-masa sulit, maka perlunya prajurit untuk dapat mengembangkan Psychological Capital.

Oleh karena itu pentingnya seorang pemimpin yang melayani di instansi militer guna dapat mempengaruhi prajuritnya dalam mengembangkan mentalnya menjadi lebih positif dan dapat lebih siap dalam melaksanakan segala tugas yang di berikan. Tujuan penelitian ini adalah mengetahui pengaruh Servant Leadership terhadap Psychological Capital prajurit TNI AD di Pusat Pendidikan Infanteri, melihat bagaimana kondisi Psychological Capital prajurit TNI AD di Pusat Pendidikan Infanteri, dan bagaimana Servant Leadership yang dinilai oleh prajurit TNI AD terhadap pemimpin di Pusat Pendidikan Infanteri. Hipotesis utama dari penelitian ini adalah mengukur adakah pengaruh Servant Leadership terhadap Psychological Capital prajurit TNI ADdi Pusat Pendidikan Infanteri.

\section{Metode}

\section{Rancangan Penelitian}

Jenis penelitian yang digunakan adalah jenis penelitian kuantitatif. penelitian yang digunakan adalah penelitian kuantitatif korelasional. Penelitian korelasional adalah penelitian yang bertujuan menyelidiki sejauh mana variasi pada satu variabel berkaitan dengan variasi pada satu atau lebih variabel lain, berdasarkan koefisien korelasi (Azwar 2005:8). Variabel bebas dalam penelitian ini adalah Servant Leadership, sedangkan variabel tergantungnya yaitu Psychological Capital.

\section{Alat ukur}


Alat ukur atau kuesioner yang dibuat terkait tentang pemimpin Servant Leadership di Pusat Pendidikan Infanteri. Alat ukur servant leadership dibuat Penelitian ini menggunakan instrument skala milik Barbuto dan Wheeler (2006) yang diadaptasi oleh Handoyo (2010). Instrument atau skala ini terderi dari 5 dimensi yakni alturistic calling, emotional healing, wisdom, persuasive mapping, dan organizational stewardship. Pada instrumen atau skala ini selain memakai 5 dimensi yang dikemukakan juga menambahkan 3 dimensi lainnya yakni vision, service, dan humality dari Wong dan Page (2003). Hal ini di lakukan karena dimensi-dimensi tersebut banyak disebutkan juga peneliti sebelumnya sebagai dimensi dalam kepemimpinan Servant Leadership. Untuk menguji reliabilitas pada penelitian ini, Peneliti melakukan uji reliabilitas dengan uji Contruct Reliability dengan skala statistik mc'donalds omega yang terdapat pada program JASP versi 0.12 .2 .

Table 1 uji reliabilitas Servant Leadership

\begin{tabular}{|c|c|c|}
\hline RELIABILITAS & MCDONALD'S $\boldsymbol{\omega}$ & KETERANGAN \\
\hline Servant Leadership & 0.906 & Reliable \\
\hline
\end{tabular}

Pengukuran Psychological Capital menggunakan kuesioner Psychological Capital Questionare (PCQ) yang dibuat oleh Luthans, Youssef, \& Avolio (2007). Penelitian ini menggunakan instrument PCQ yang sudah di terjemahkan oleh peneliti sendiri. Psychological Capital Questionare ini memiliki 24 item yang terdiri dari empat komponen yaitu self efficacy, optimism, hope, dan resiliency. Setiap komponen, yang diwakili oleh 6 item ini, berasal dari alat ukur berbeda yang kemudian diadaptasi menjadi PCQ. Pada PCQ, komponen self efficacy mengacu pada alat ukur self efficacy milik Parker (1998), komponen hope berasal dari alat ukur Snyder (2003), komponen optimism pada PCQ dikembangkan dari alat ukur Scheier dan Carver (1985), dan komponen resilience dikembangkan dari alat ukur Wagnild dan Young (1993). Untuk menguji reliabilitas pada penelitian ini, Peneliti melakukan uji reliabilitas 
dengan uji Contruct Reliability dengan skala statistik mc'donalds omega yang terdapat pada program JASP versi 0.12.2.

Table 2 uji reliabilitas Psychological capital

\begin{tabular}{|c|c|c|}
\hline RELIABILITAS & MCDONALD'S $\boldsymbol{\omega}$ & KETERANGAN \\
\hline $\begin{array}{c}\text { Psychological } \\
\text { capital }\end{array}$ & 0,902 & Reliable \\
\hline
\end{tabular}

\section{Sampel}

Sampel penelitian ini sebanyak 147 prajurit pusdikif berpangkat 42 perwira, 53 bintara dan 52 tamtama yang bekerja di Pusat Pendidikan Infanteri.

\section{Data demografi}

\section{Table 3 demografi}

\begin{tabular}{|c|c|}
\hline Pangkat & Jumlah \\
\hline Perwira & 42 \\
\hline Bintara & 53 \\
\hline Tamtama & 52 \\
\hline
\end{tabular}

\begin{tabular}{|c|c|c|c|c|c|c|}
\hline Lama Kerja & Perwira & $\%$ & Bintara & $\%$ & Tamtama & $\%$ \\
\hline 0-5 Tahun & - & & 8 & $15 \%$ & 8 & $15 \%$ \\
\hline 5-10 Tahun & 6 & $14,2 \%$ & 18 & $34 \%$ & 28 & $54 \%$ \\
\hline 10-20 Tahun & - & & 9 & $17 \%$ & 8 & $15 \%$ \\
\hline 20 tahun keatas & 36 & $86 \%$ & 18 & $34 \%$ & 8 & $15 \%$ \\
\hline
\end{tabular}

Pada tabel lama kerja dari 147 prajurit pada pangkat perwira mendapatkan total 42 prajurit dengan rentang lama kerja 5-10 tahun 6 prajurit (14,2\%) dan 20 tahun keatas sebanyak 36 prajurit (86\%), sedangkan pada pangkat bintara total 53 prajurit dengan rentang lama kerja 0-5 tahun 8 prajurit (15\%), 5-10 tahun 18 prajurit (34\%), 10-20 tahun 9 prajurit (17\%) dan 20 tahun ke atas 18 prajurit (17\%). Pada pangkat tamtama dengan total 52 reponden dengan rentang kerja 0-5 tahun 8 prajurit (15\%) 5-10 tahun 28 prajurit (54\%) 10-20 tahun 8 prajurit (15\%) dan 20 tahun keatas 8 prajurit (15\%). 


\section{Teknik sampling}

Teknik pemilihan sampel dalam penelitian ini adalah probability sampling, peneliti menyebarkan kuesioner kepada seluruh prajurit TNI-AD dan terkumpul 147 kuesioner.

\section{Hasil dan Pembahasan}

\section{Hasil}

Table 4 Hasil Uji Regresi Linier Berganda

\begin{tabular}{|c|c|c|c|c|c|c|}
\hline \multicolumn{5}{|c|}{ Model Summary - Psychological Capital } & & \\
\hline Model & $\mathbf{R}$ & $\mathbf{R}^{2}$ & Adjusted $\mathbf{R}^{2}$ & RMSE & & \\
\hline $\mathrm{H}_{0}$ & 0.000 & 0.000 & 0.000 & 8.641 & & \\
\hline $\mathrm{H}_{1}$ & 0.685 & 0.469 & 0.438 & 6.478 & & \\
\hline \multicolumn{7}{|c|}{ ANOVA } \\
\hline Model & & Sum of Squares & df & Mean Square & $\mathbf{F}$ & $\mathbf{p}$ \\
\hline \multirow[t]{3}{*}{$\mathrm{H}_{1}$} & Regression & 5109.405 & 8 & 638.676 & 15.220 & $<.001$ \\
\hline & Residual & 5790.853 & 138 & 41.963 & & \\
\hline & Total & 10900.259 & 146 & & & \\
\hline
\end{tabular}

\begin{tabular}{|c|c|c|c|c|c|c|c|c|}
\hline \multicolumn{9}{|c|}{ Coefficients } \\
\hline \multirow[b]{2}{*}{ Model } & & \multirow[b]{2}{*}{ Unstandardized } & \multirow[b]{2}{*}{$\begin{array}{c}\text { Standard } \\
\text { Error }\end{array}$} & \multirow[b]{2}{*}{ Standardized } & \multirow[b]{2}{*}{$\mathbf{t}$} & \multirow[b]{2}{*}{$\mathbf{p}$} & \multicolumn{2}{|c|}{$\begin{array}{c}\text { Collinearity } \\
\text { Statistics } \\
\end{array}$} \\
\hline & & & & & & & Tolerance & VIF \\
\hline $\mathrm{H}_{0}$ & (Intercept) & 92.558 & 0.713 & & 129.876 & $<.001$ & & \\
\hline \multirow[t]{9}{*}{$\mathrm{H}_{1}$} & (Intercept) & 43.007 & 6.000 & & 7.168 & $<.001$ & & \\
\hline & Alruistic Calling & 0.485 & 0.351 & 0.125 & 1.381 & 0.170 & 0.466 & 2.144 \\
\hline & $\begin{array}{l}\text { Emotional } \\
\text { Healing }\end{array}$ & -0.164 & 0.348 & -0.039 & -0.470 & 0.639 & 0.552 & 1.813 \\
\hline & Wisdom & 1.669 & 0.368 & 0.423 & 4.534 & $<.001$ & 0.443 & 2.258 \\
\hline & $\begin{array}{l}\text { Persuasive } \\
\text { Mapping }\end{array}$ & -0.630 & 0.366 & -0.147 & -1.722 & 0.087 & 0.532 & 1.881 \\
\hline & $\begin{array}{l}\text { Organizational } \\
\text { Stewardship }\end{array}$ & -0.227 & 0.345 & -0.061 & -0.659 & 0.511 & 0.449 & 2.226 \\
\hline & Humility & 0.564 & 0.302 & 0.190 & 1.868 & 0.064 & 0.373 & 2.681 \\
\hline & vision & 0.763 & 0.330 & 0.207 & 2.313 & 0.022 & 0.483 & 2.071 \\
\hline & service & 0.166 & 0.367 & 0.040 & 0.453 & 0.651 & 0.489 & 2.045 \\
\hline
\end{tabular}


Berdasarkan hasil Uji Regresi Linier Berganda didapatkan pengaruh Servant Leadership terhadap Psychological Capital secara keseluruhan sebesar 0.469 atau 46\%. Didapatkan juga $\mathrm{P}$ value sebesar $<.001$, artinya Independent Variabel (Alruistic Calling, Emotional Healing, Wisdom, Persuasive Mapping, Organizational Stewardship, Humility, vision, service) secara bersama sama dapat memprediksi Dependent Variabel (Psychological Capital). Serta didapatkan Nilai koefisien regresi pada dimensi Alruistic Calling sebesar 0,485. Nilai koefisien regresi pada dimensi Emotional Healing sebesar 0,164. Nilai koefisien regresi pada dimensi Wisdom sebesar 1,669. Nilai koefisien regresi pada dimensi Persuasive Mapping sebesar -0,630. Nilai koefisien regresi pada dimensi Organizational Stewardship sebesar $-0,227$. Nilai koefisien regresi pada dimensi Humility sebesar 0,564. Nilai koefisien regresi pada dimensi vision sebesar 0,763. Nilai koefisien regresi pada dimensi service sebesar 0,166. Artinya, Pengaruh dimensi Wisdom terhadap Psychological capital lebih besar pengaruhnya dibanding dimensi lainya. (Alruistic Calling, Emotional Healing, Persuasive Mapping, Organizational Stewardship, Humility, vision, service).

\section{Pembahasan}

Situasi kerja yang dihadapi Prajurit merupakan tanggung jawab seorang pemimpin. Bagaimana seorang pemimpin harus mampu memliki kapabilitas dalam mengarahkan prajuritnya dengan baik serta dapat mesejahterakan prajurit. Hasil penilitian menunjukan pengaruh langsung Servant Leadership dapat memprediksi terhadap Psychological Capital Prajurit. Hasil penelitian yang didapatkan pengaruh sebesar 0.469 atau 46\%. Hasil ini menunjukan bahwa faktor-faktor Servant Leadership mempengaruhi tinggi rendahnya Psychological Capital Prajurit.

Pada aspek Alruistic Calling didapatkan hasil uji statistik sebesar 0,485. Mengambarkan pemimpin mampu memberikan perbedaan positif pada kehidupan prajurit serta memiliki keyakinan bahwa pemimpin bekerja keras untuk memenuhi kebutuhan Prajurit di banding kebutuhannya sendiri. Hal ini pun sejalan dengan salah satu 11 azaz kepemimpinan TNI AD yaitu Satya, merupakan sikap loyal yang timbal balik, dari atasan terhadap bawahan, dari bawahan terhadap atasan dan 
kesamping. Hal ini dapat berpengaruh terhadap Prajurit dalam memandang pemimpin yang peduli dan selalu memberikan ide-ide sebagai sebuah motivasi yang dapat membuat suatu perbedaan positif bagi Prajurit. Artinya semakin tinggi Alruistic Calling maka tingkat Psychological Capital Prajurit semakin meningkat. Sedangkan pada aspek Emotional Healing hasil uji statistik sebesar -0.164. Mengambarkan pemimpin adalah seorang yang dapat mendengarkan, berempati, dan menyembuhkan serta mengarahkan prajurit pada rasa kesejahteraan yang lebih tinggi. Hal ini sejalan dengan "ing madya mangun karsa, yaitu ikut bergiat serta menggugah semangat di tengah-tengah anak buah.” Dari 11 azaz kepemimpin TNI AD. Menjadikan aspek Emotional Healing suatu predictor yang kuat terhadap Psychological Capital namun pada hasil penelitian menyatakan bahwa dalam pengaruhnya Emotional Healing menunjukan hasil negative yang artinya pemimpin mampu berikan Emotional Healing terhadap Prajurit namun hal tersebut tidak memprediksi pengaruhnya terhadap Psychological Capital Prajurit itu sendiri. Hasil ini mendukung penelitian dari Paul Nebrian Mahdi (2014) bahwa terdapat hubungan yang siginifikan antara servant leadership dengan opitimisme, disebabkan karena karakteristik Servant yang terfokus pada anggotanya dan juga berusaha membantu para anggotanya untuk keluar dari penderitaan dan menjadi individu yang lebih baik di tunjukan oleh dimensi Altruistic calling dan emotional healing, maka dapat di artikan Ketika pemimpin memiliki aspek Altruistic calling dan emotional healing maka akan meningkatkan salah satu aspek Psychological Capital yaitu opitimisme.

Pada aspek Wisdom didapatkan hasil uji statistik sebesar 1.669. Mengambarkan kebijaksanaan pemimpin, ketika mampu memahami situasi dan implikasi dari situasi lingkungan kerja. Dalam 11 azaz kepemimpinan TNI AD di artikan sebagai "waspada purba wisesa, yaitu selalu waspada, mengawasi serta sanggup dan berani memberi koreksi kepada anak buah.” Maka Setiap keputusan yang dibuat oleh pemimpin akan berpengaruh terhadap Prajurit sehingga pemimpin mampu memprediksi apa yang terjadi di lingkungan kerja, setiap koreksi yang diberikan terhadap Prajurit merupakan upaya dalam memberikan motivasi dari seorang pemimpin bagi Prajuritnya. Hal ini karena pencapaian harapan dapat 
terwujud, diperlukan motivasi yang tinggi dari diri seorang individu. Luthans, Youssef \& Avolio, (2007). Artinya semakin tinggi Wisdom maka tingkat Psychological Capital semakin meningkat.

Sedangkan aspek Persuasive Mapping mendapatkan hasil uji statistik hasil sebesar -0.630, Mengambarkan pemimpin yang dapat memberikan inspirasi, keyakinan dalam visi, dan motivasi terhadap Prajurit. Hal ini sejalan dengan azaz kepemimpinan TNI AD "belaka, yaitu kemauan, kerelaan dan keberanian untuk mempertanggungjawabkan tindakan-tindakannya." Artinya pemimpin dapat memberikan inspirasi dan motivasi di tengah-tengah latihan dan memberikan arahan terhadap prajurit dalam memiliki keyakinan untuk bangkit sehingga memiliki pandangan yang lebih optimis di masa depan. Namun pada hasil penelitian menunjukan hasil negative yang artinya semakin tinggi Persuasive Mapping namun hal tersebut tidak memprediksi pengaruhnya terhadap Psychological Capital Prajurit itu sendiri

Pada aspek Organizational Stewardship hasil uji statistik didapatkan hasil sebesar -0.227. Mengambarkan pemimpin dalam melibatkan Prajurit meciptakan lingkungan kerja yang nyaman dan menyadari bahwa jabatan yang di miliki merupakan sebuah tanggung jawab yang besar. Hal ini sejalan dengan azaz kepemimpinan TNI AD "ambeg parama arta, yaitu dapat memilih dengan tepat mana yang harus dilakukan." Namun pada hasil penelitian menunjukan hasil negative yang artinya semakin tinggi Organizational Stewardship tidak memprediksi pengaruhnya terhadap Psychological Capital prajurit. Sedangkan Pada aspek Humility didapatkan hasil uji statistik sebesar 0.564. Mengambarkan pemimpin dekat dengan prajuritnya tanpa memandang pangkat, dan menghargai setiap prestasi prajuritnya. Dalam 11 azaz kepemimpinan TNI AD dapat di artikan sebagai "prasaja, yaitu tingkah laku yang sederhana dan tidak berlebih-lebihan." Artinya pemimpin memiliki kerendahan hati dan memandang jabatan yang di pegangnya adalah sebuah tanggungjawab bukan hanya untuk kepentingan sendiri namun untuk kepentingan Prajurit. Hasil penelitian menunjukan tingginya Humility maka tingkat Psychological Capital Prajurit semakin meningkat. Artinya prajurit memandang bahwa pemimpin yang memiliki kerendahan hati merupakan seorang 
pemimpin panutan bagi mereka dan percaya bahwa seorang pemimpin dapat mesejahterakan para prajurit.

Pada aspek vision didapatkan hasil uji statistik sebesar 0.763 . Mengambarkan pemimpin memiliki tujuan terhadap kesatuan dan Prajurit. Bagaimana pemimpin mengajak bersama-sama Prajurit dalam visi kesatuan dan melibatkan langsung Prajurit karena semakin tinggi Vision maka tingkat Psychological Capital semakin meningkat. Dapat di artikan jiwa korsa prajurit dapat tumbuh karena pengaruh pemimpin itu sendiri bagaimana seorang Prajurit memiliki keyakinan harapan serta kebanggaan dirinya terhadap kesatuan. Pada aspek terakhir service mengambarkan pemimpin mampu menjadi contoh dalam memberikan pelayanan kepada prajurit baik dalam perilaku sikap atau nilai pribadinya. Bila digambarkan pada azaz kepemimpinan TNI AD adalah "ing ngarsa sung tulada, yaitu memberi suri teladan dihadapan anak buah". Artinya pemimpin dapat menjadi role model bagi Prajurit serta dapat melayani kebutuhan prajuritnya karena service yang di berikan pemimpin terhadap Prajurit mampu memprediksi Psychological Capital Prajurit menjadi lebih baik. Selain itu, prajurit menjadikan pemimpin sebagai contoh nyata dalam hal kepemimpinan, bagaimana akhirnya prajurit mampu memiliki harapan dan keyakinan ketika menjadi seorang pemimpin mengedepankan sikap, perilaku, dan nilai pribadinya.

Pada hasil penelitian Psychological Capital didapat 3 aspek yang di dominasi oleh pangkat bintara yaitu self efficacy, hal ini merupakan konsep diri seseorang yang percaya terhadap efikasi personal. Hope atau harapan didefinisikan sebagai sebuah perencanaan dan aksi yang efektif yang dapat memberikan hasil yang jelas. Optimism didefinisikan sebagai kecenderungan untuk mengharapkan kejadian positif dalam kehidupan. Perilaku optimisme memiliki target untuk mendapatkan apa yang diinginkan serta percaya pada kemampuan untuk mencapai suatu tujuan. Artinya Prajurit dengan pangkat bintara memilik modal psikologis yang dominan di antara pangkat perwira dan tamtama. Karena mereka berada di pangkat menengah yang memiliki sebuah perencanaan dan keyakinan untuk berkembang serta memiliki harapan untuk karir yang lebih baik di masa yang akan datang. Dari perolehan data demografi lama kerja pangkat bintara sudah bekerja di 
atas 10 tahun artinya seorang Prajurit sudah memiliki pengalaman yang cukup dalam bekerja menjadi seorang Prajurit TNI AD.

Sedangkan aspek Resilience didefinisikan sebagai kemampuan untuk berhadapan dengan keadaan negatif, resiko, dan perubahan yang penting Luthans (dalam Nafei, 2015). Resiliensi dominan oleh pangkat perwira yang artinya para perwira lebih siap untuk melewati kesulitan yang di hadapi, hal ini terjadi karena kecenderungan perwira dalam karirnya lebih banyak melalui rintangan dan dituntut menjadi seorang pemimpin di masa depan. Hal ini pun di dukung oleh data demografi lama kerja dimana pangkat perwira sudah berkerja di atas 20 tahun yang membuat pangkat perwira memiliki pengalaman yang lebih baik. Sedangkan pada sampel tamtama menunjukan lama kerja di bawah 10 tahun artinya lama kerja bisa jadi prediktor tidak memprediksinya Psychological Capital pada pangkat tamtama. Hasil penelitian di peroleh rarata yang tidak menunjukan perbedaan yang signifikan antara pangkat perwira, bintara dan tamtama, hal ini mengartikan bahwa perlakuan pemimpin terhadap Prajurit sama tanpa membedakan pangkat Prajurit.

Hal ini mendukung hasil penelitian Psikologi Militer Sait Gurbuz a (2018) tentang Psychological Capital dalam studinya menunjukkan bahwa mereka yang memiliki PsyCap lebih tinggi lebih cenderung menggambarkan kinerja tugas lebih baik, serta berkomitmen pada organisasi mereka, dan sangat puas dengan pekerjaan mereka di lingkungan militer. Penelitian lain dari Eduardo Hernández-Varas (2019) memperoleh korelasi positif dan signifikan terdeteksi antara variabel Psychological Capital, Work Satisfaction dan Health Self-Perception mampu memprediksi Psychological Wellbeing, semuanya menjelaskan hingga 53\%. Prediktor yang paling penting adalah Psychological Capital yang bertanggung jawab atas $80 \%$ dari keseluruhan. Dengan Kesimpulan karena kekuatan prediksi yang signifikan dari Psychological Capital atas work satisfaction dan health self-perception pengembangan program yang bertujuan untuk meningkatkan Psychological Capital mungkin memiliki hasil positif terhadap Psychological Wellbeing prajurit militer. 


\section{Kesimpulan}

Berdasarkan hasil penelitian mengenai Pengaruh Servant Leadership Terhadap Psychological Capital Prajurit TNI AD di Pusat Pendidikan Infanteri dapat disimpulkan hal-hal sebagai berikut: Terdapat pengaruh yang signifikan antara Servant Leadership terhadap Psychological Capital Prajurit TNI AD di Pusat Pendidikan Infanteri, yaitu sebesar 46\%. Servant Leadership pada aspek wisdom memberikan pengaruh tertinggi terhadap Psychological Capital Prajurit TNI AD di Pusat Pendidikan Infanteri. Pada aspek Emotional Healing, Persuasive Mapping, dan Organizational Stewardship, 3 dimensi tersebut tidak langsung mempengaruhi Psychological Capital Prajurit TNI AD di Pusat Pendidikan Infanteri Hasil Psychological Capital prajurit sebanyak 147 responden penelitian, tidak terjadi perbedaan yang signifikan antara pangkat Perwira, Bintara dan Tamtama. Pangkat bintara mendominasi Psychological Capital pada aspek self efficacy, hope, dan Optimism. Sedangkan Perwira pada aspek Resilience.

\section{Daftar Pustaka}

A. Gregory Stone, R. F. (2004). Transformational versus servant leadership: a difference in leader focus. The Leadership \& Organization Development Journal Vol. 25 No. 4, 349-361.

Abdullah, M. C. (2009). Leadership And Psycap: A Study Of The Relationship Between Positive Leadership Behaviors And Followers' Positive Psychological Capital. Capella University.

AD, P. P. (2011). Sejarah pusat pendidikan infanteri. Bandung .

Calva gonzález, j. J. (1999). Ranjit Kumar. Research methodology: a step-by-step guide for beginners. Investigación Bibliotecológica: Archivonomía, Bibliotecología e Información.

Chen, S.-L. (2015). The relationship of leader psychological capital and follower psychological capital, job engagement and job performance: a multilevel mediating perspective. The International Journal of Human Resource Management Vol. 26, No. 18,, 2349-2365.

Coggins, E. D. (2012). The Relationship of Followers' Perceptions of Leaders' Servant Leadership Behaviors to Followers' Self-Ratings of the Four 
Components of Psychological Capital: A Comparative Study of Evangelical Christian Leader-Follower Relationships in the United States.

Dennis, R. (2003). A factor analysis of Page and Wong's servant leadership instrument. Leadership and Organizational Development Journal 24, 455459.

Dumatubun, N. F. (2018). Pengaruh Servant Leadership Terhadap Motivasi Kerja,Kinerja Karyawan Dan Komitmen Organisasi. tesis Fakultas Ekonomi, Universitas Sanata Dharma.

Eric D. Coggins, M. C. (2015). The Impact of Servant Leadership to Followers' Psychological Capital: A Comparative Study of Evangelical Christian Leader-Follower Relationships in the United States and Cambodia. Journal of Leadership, Accountability and Ethics Vol. 12(4).

Greenleaf, R. K. (1970). The servant as a leader. Indianapolis. Greenleaf Center.

Greenleaf, R. K. (1977). Servant leadership: A journey into the nature of legitimate power and greatness. New York, NY: Paulist Press.

Gurbuz, S. \&. (2019). Working in the hangar: The impact of psychological capital on work outcomes among army aircraft mechanics. Military Psychology, $60-70$.

Handoyo, S. (2010). Pengukuran Servant Leadership Sebagai Alternatif Kepemimpinan Di Institusi Pendidikan Tinggi Pada Masa Perubahan Organisasi. Makara, Sosial Humaniora, VOL. 14, NO. 2, , 130-140.

https://www.tni.mil.id/. (n.d.).

https://www.tribunnews.com/tribunners/2017/11/22/panglima-tni-keberhasilantugas-milik-anak-buah-kegagalan-tanggung-jawab-komandan. (n.d.).

Julianti1, A. (2015). Pengaruh Psychological Capital Terhadap Komitmen Organisasi Dan Perilaku Kewargaorganisasian Pada Karyawan. Jurnal Psikologi ol. 8 No. 2.

Kencana Anggar Kusuma, U. P. (2016). Hubungan Antara Psychological Capital Dengan Disiplin Kerja Karyawanbagian Produksi Pt. Argamas Lestari Semarang. Jurnal Empati, 317-321.

Kurniawan, T. (2019). Pengaruh Servant Leadership Terhadap Kinerja Karyawan Dipt. Tata Mulia Nusantara Indah Dengan Persepsi Budaya Organisasional Sebagai Mediasi. Agora Volume 7. No : 1,, 121-131.

Lailatul Munawaroh1, \&. I. (2012). Peranan Psychological Capital terhadap Kesiapan Individu untuk Berubah yang Dimoderatori oleh Persepsi Dukungan Organisasi. Jurnal Psikologi Volume 44, Nomor 3, 198-210.

Luthans, F. Y. (2007). Psychological capital: Developing the human competitive edge. New York: : Oxford University Press. 
Luthans, F., Avolio, B. J., Avey, J. B., \& and Norman, S. M. (2007). Positive Psychological Capital: Measurement and Relationship with Performance and Satisfaction. Leadership Institute Faculty Publications.

Mikko, M. (2012). Hubungan Antara Psychological Capital Dan Komitmen Organisasi Pada Perawat. Skripsi, Fakultas Psikologi Universitas Indonesia.

Nugroho, D. A. (2013). Hubungan Antara Psychological Capital Dengan Work Engagement Pada Karyawan Pt. Bank Mega Regional Area Semarang. Jurnal Psikologi Undip Vol.12 No.2 Oktober 2013.

Paul Nebrian Mahdi, B. S. (2014). Hubungan Antara Gaya Kepemimpinan Servant Leadership Dan Optimisme Menurut Persepsi Anggota Rumah Singah Peka. Fakultas Psikologi Universitas Indonesia.

Purwanto, S. \&. (2004). Metodologi Penelitian. Jakarta: Gramedia Pustaka Utama.

Sardi, S. (2017). Pengaruh Gaya Kepemimpinan Transformasional Dan Transaksional Terhadap Kinerja Bawahan Melalui Kepuasan Kerja. JBTI : Jurnal Bisnis Teori Dan Implementasi, 1-11.

Silalahi. (2012). Metode Penelitian Sosial. bandung: PT refika aditama.

Spears, L. (2002). On character and servant leadership: Ten characteristics of effective, caring leaders.

Sugiyono. (2008). Metode Penelitian Kuantitatif Kualitatif Dan R\&Da. bandung: alfabeta.

Varas, E. H. (2019). Psychological capital, work satisfaction and health selfperception as predictors of psychological wellbeing in military personnel. Psicothema, 277-283.

Wong, P. \&. (2003). Servant leadership: An opponent-process model and the revised servant Leadership profile.

Yukl, G. (2010). Kepemimpinan Dalam Organisasi, Edisi Kelima. Jakarta: PT indeks. 